\title{
Activity of Anti-Microbial Peptides (AMPs) against Leishmania and Other Parasites: An Overview
}

\author{
Rima El-Dirany ${ }^{1,2}$, Hawraa Shahrour ${ }^{2,3,+} \mathbb{D}$, Zeinab Dirany ${ }^{4,+}$, Fadi Abdel-Sater ${ }^{2}$, Gustavo Gonzalez-Gaitano ${ }^{4} \mathbb{D}$, \\ Klaus Brandenburg ${ }^{5}$, Guillermo Martinez de Tejada ${ }^{3}$ (D) and Paul A. Nguewa ${ }^{1, *(D)}$
}

1 ISTUN Instituto de Salud Tropical, Department of Microbiology and Parasitology, IdiSNA (Navarra Institute for Health Research), University of Navarra, c/Irunlarrea 1, 31008 Pamplona, Navarra, Spain; reldirany@alumni.unav.es

2 Faculty of Sciences I, Lebanese University, Hadath 1003, Lebanon; hshahrour@alumni.unav.es (H.S.); fabdelsa@ul.edu.lb (F.A.-S.)

3 Department of Microbiology and Parasitology, IdiSNA (Navarra Institute for Health Research), University of Navarra, 31008 Pamplona, Navarra, Spain; gmartinez@unav.es

4 Department of Chemistry, Faculty of Sciences, University of Navarra, 31080 Pamplona, Navarra, Spain; zdiranyahma@alumni.unav.es (Z.D.); gaitano@unav.es (G.G.-G.)

5 Brandenburg Antiinfektiva GmbH, c/o Forschungszentrum Borstel, Leibniz Lungenzentrum, 23845 Borstel, Germany; kbranden@gmx.de

* Correspondence: panguewa@unav.es

+ These authors contributed equally to this work.

check for updates

Citation: El-Dirany, R.; Shahrour, H.; Dirany, Z.; Abdel-Sater, F.; GonzalezGaitano, G.; Brandenburg, K.; Martinez de Tejada, G.; Nguewa, P.A. Activity of Anti-Microbial Peptides (AMPs) against Leishmania and Other Parasites: An Overview. Biomolecules 2021, 11, 984. https://doi.org/10.3390/ biom11070984

Academic Editor: Marc Maresca

Received: 22 May 2021

Accepted: 26 June 2021

Published: 4 July 2021

Publisher's Note: MDPI stays neutral with regard to jurisdictional claims in published maps and institutional affiliations.

Copyright: (c) 2021 by the authors. Licensee MDPI, Basel, Switzerland. This article is an open access article distributed under the terms and conditions of the Creative Commons Attribution (CC BY) license (https:// creativecommons.org/licenses/by/ $4.0 /)$.

\begin{abstract}
Anti-microbial peptides (AMPs), small biologically active molecules, produced by different organisms through their innate immune system, have become a considerable subject of interest in the request of novel therapeutics. Most of these peptides are cationic-amphipathic, exhibiting two main mechanisms of action, direct lysis and by modulating the immunity. The most commonly reported activity of AMPs is their anti-bacterial effects, although other effects, such as anti-fungal, anti-viral, and anti-parasitic, as well as anti-tumor mechanisms of action have also been described. Their anti-parasitic effect against leishmaniasis has been studied. Leishmaniasis is a neglected tropical disease. Currently among parasitic diseases, it is the second most threating illness after malaria. Clinical treatments, mainly antimonial derivatives, are related to drug resistance and some undesirable effects. Therefore, the development of new therapeutic agents has become a priority, and AMPs constitute a promising alternative. In this work, we describe the principal families of AMPs (melittin, cecropin, cathelicidin, defensin, magainin, temporin, dermaseptin, eumenitin, and histatin) exhibiting a potential anti-leishmanial activity, as well as their effectiveness against other microorganisms.
\end{abstract}

Keywords: anti-microbial peptides (AMPs); anti-bacterial; anti-fungal; anti-viral; anti-parasitic; anti-tumor; Leishmania; parasite; bacteria; Cathelicidin; Cecropin; Defensin; Dermaseptin; Eumentin; Histatin; Magainin; Melittin; Temporin

\section{Introduction}

Anti-microbial peptides (AMPs), also called host defense peptides (HDP), are a growing class of peptide-based molecules, with a wide spectrum of biological activities. They are small peptides, consisting of 5-100 amino acid residues with diverse molecular weights [1,2]. Several living organisms, such as bacteria, fungi, plants, invertebrates, non-mammalian vertebrates, and mammals, generate AMPs [3]. They are involved in innate immunity and the induction of resistance against such anti-microbial peptides is uncommon [4]. AMPs exhibit broad-spectrum anti-microbial properties, acting by the direct elimination of infectious pathogens (bacteria, viruses, fungi, and parasites) or by modulating the immune response. They activate and recruit immune cells resulting in the 
enhancement of the pathogen elimination and/or in the control of inflammation, wound healing, and angiogenesis $[5,6]$.

Furthermore, AMPs may act as signaling molecules, biomarkers, and also as antitumor agents [7]. These peptides are mainly cationic and amphipathic, harboring hydrophobic residues (normally 50\%). In total, more than 3000 natural AMPs have been identified so far (APD: Anti-microbial Peptide Database; http:/ /aps.unmc.edu/AP/ (accessed on September 2020) and were principally from eukaryotes [2,8]. AMPs are not only isolated from amphibians, birds, fishes, mammals, insects and other invertebrates, and plants, but also from bacteria [3,9-11]. In insects, AMPs are produced in the fat body and the hemocytes or epithelia [12]. In vertebrates, AMPs are detected in mammals (in lymphocytes and leukocytes) [13,14]; they were also present in amphibian skin secretions [15] and epithelia [16]. Indeed, more than 300 distinct AMPs were isolated from the frog skin [17]. AMPs are also produced by human cells, including immune cells (phagocytes as well as lymphocytes) [18], and gastrointestinal epithelial cells [19].

AMPs can be divided into subgroups depending on their sequences and structures [20]. Several classes of AMPs have been identified, including cecropins, magainins, melittin, dermaseptins, defensins, and cathelicidins, which are cationic peptides of $\sim 20-50$ amino acids. Interestingly, cathelicidins and defensins are the main groups [21] and AMPs can be fully synthetized or modified chemically [22]. Such chemical modifications may allow altering of the target sites of the peptides and to enhance their resistance against proteolytic enzymes [23].

AMPs were first used to fight the antibiotic resistance of microorganisms [7], since these compounds are not affected by the mechanisms of bacterial resistance to conventional anti-microbials. The increase of multi-drug resistant (MDR) bacteria, due to the excessive use and misuse of antibiotics, is a critical issue. In the clinic, the death rates and the period of hospitalization is much higher in patients infected with drug-resistant organism $[7,24]$, and the healthcare burden due to the proliferation of MDR bacteria has dramatically augmented in recent years [25]. This rapid increase in antibiotic resistance is alarming, according to the World Health Organization (WHO) [26]. In this sense, AMPs were highlighted as substitutes of conventional antibiotic agents, since these compounds can be readily modified to minimize their intrinsic limitations, such as toxicity, excessive length, and degradation by host proteases [27-29].

A common characteristic of AMPs is their fast inhibitory activity. In addition, some of them are able to even lysate within seconds following the interaction with the target's membrane (Figure 1). This activity is mainly a result of the amphipathic conformation of AMPs that enhances their ability to contact the hydrophobic part of the lipid components and to the hydropholic part of phospholipid polar groups, causing the complete disruption and permeabilization of the bacterial membrane [1]. A wide range of their biological activities has been described, with the anti-microbial activity being the most commonly investigated, specifically against bacteria (anti-bacterial activity). When dealing with their activity on parasites, among the 990 active AMPs registered at the APD database, only 83 peptides have been assessed as anti-parasitic agents, mainly against malaria [30], while the anti-leishmanial activity of many AMPs families has only been studied in recent years.

Leishmaniasis, a parasitic illness caused by Leishmania species, is transmitted to humans through vectors (phlebotomine sand flies) [31]. Leishmaniasis is considered by $\mathrm{WHO}$ as a neglected tropical disease. After malaria, it is the most worrying parasitic illness worldwide [32]. About $0.7-1$ million new cases of leishmaniasis are reported annually, generating around 20,000-30,000 deaths, according to WHO [33]. Leishmania parasites have a complex life cycle consisting of two stages: promastigote in the vector sandfly and amastigote in mammalian hosts. Promastigotes have a motile flagellum and elongated shape. Once infecting the macrophages, they differentiate to nonmotile amastigotes with very short flagellum and ovoid cell body [34]. Over 20 Leishmania species are known to be infective to humans, classified into old world (Mediterranean countries, Asia, and Africa) and new world parasites (America) [35]. On the other hand, among 800 species of sandflies, 
only Phlebotomus species and subspecies in the Old World and Lutzomyia in the New World, are proven as vectors for human leishmaniasis [36]. However, the parasite could be in few cases transmitted from mother to child during pregnancy [37], by syringe sharing [38], or blood transfusions [39]. Depending on the characteristics of the parasite and the vector sandfly, the disease is manifesting in three main types: cutaneous, mucocutaneus, and visceral. Cutaneous leishmaniasis constitutes $90 \%$ of the cases and causes skin lesions that can evolve to life-long ulcers while mucocutaneus leishmaniasis is a rare form of the disease associated with the inadequate treatment of the primary infection and causes both skin and mucosal ulcers. Visceral leishmaniasis occurs when the parasite reaches the internal organs, it is considered the most severe form and can be lethal if left untreated [40]. Generic pentavalent antimonials have been the first-line drugs against this pathology [41], but these present limitations, such as drug resistance and severe side effects [42]. Therefore, alternative treatments based on amphotericin B, miltefosine, and paramomycin, were also approved.

Amphotericin B is a polyene antibiotic that offers a high efficacy, but its high cost and difficulty of intravenous administration limit its clinical use [35,43]. Similarly, miltefosine, a recognized oral agent used for leishmaniasis treatment, is a costlier option compared to antimonials [44]. Paromomycin, a natural aminoglycoside antibiotic synthesized by Streptomyces riomosus, has also shown activity for the treatment of this disease. Whereas, these treatments are limited by several side effects, ranging from the mild pain at the injection site to the development of hepatic and renal toxicity [45].

Due to the aforementioned limitations that reduce the efficiency of all these compounds, in addition to the lack of an effective human vaccine against leishmaniasis [46], new therapeutic strategies and innovative reformulations are urgently needed. In this regard, isoselenocyanate derivatives, which are well known for their anti-tumor activity, were demonstrated for the first time to have potential effect on leishmaniasis [46]. Furthermore, since selenium derivatives are able to reduce parasitemia [47], some selenocompounds were also investigated and reported to exhibit leishmanicidal effect [48]. More recently, a new reformulation of miltefosine has been developed, based in the incorporation of this compound to poly(ethylene)oxide (PEO)-based polymeric micelles [49]. These formulations improved the drug's effectiveness against amastigotes, revealing itself as an encouraging methodology for the cure of leishmaniasis.

A different therapeutic approach involves the use of AMPs. Numerous AMPs, like melittin, cecropin, cathelicidin, defensin, magainin, temporin, dermaseptin, eumenitin, and histatin, have proven to be active on different Leishmania species (Table 1).

Table 1. Some AMPs exhibiting leishmanicidal activity.

\begin{tabular}{|c|c|c|c|c|}
\hline AMPs Family & Peptide Name & Sequence & Leishmania species & Reference \\
\hline \multirow{4}{*}{ 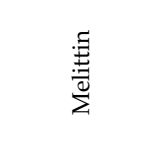 } & \multirow{4}{*}{ Melittin } & \multirow{4}{*}{ GIGAVLTTGLPALISWIKRKRQQ } & \multirow{4}{*}{$\begin{array}{c}\text { L. major } \\
\text { L. panamensis } \\
\text { L. donovani promastigotes } \\
\text { L. infantum promastigotes } \\
\text { and amastigotes }\end{array}$} & (Pereira et al., 2016) \\
\hline & & & & (5) \\
\hline & & & & (Pérez-Cordero et al., 2011) \\
\hline & & & & (Díaz-Achirica et al., 1998) \\
\hline \multirow{2}{*}{ 离 } & Cecropin-A & KWKLFKKIEKVGQNIRDGIIKAGPAVAWVGQATQIAK & \multirow{2}{*}{$\begin{array}{c}\text { Leishmania aethiopic } \\
\text { L.panamensis amastigotes } \\
\text { Leishmania }(V) \\
\text { L. panamensis promastigotes }\end{array}$} & \multirow{2}{*}{$\begin{array}{c}\text { (Pérez-Cordero et al., 2011) } \\
\text { (Akuffo et al., 1998) } \\
\text { (Patiño-Márquez et al., 2018) }\end{array}$} \\
\hline & Cecropin-D & ENFFKEIERAGQRIRDAIISAAPAVETLAQAQKIIKGGD & & \\
\hline \multirow{3}{*}{ 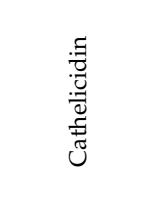 } & LL-37 & LLGDFFRKSKEKIGKEFKRIVQRIKDFLRNLVPRTES & $\begin{array}{l}\text { L. donovani promastigotes } \\
\text { and amastigotes } \\
\text { L. major amastigotes }\end{array}$ & \multirow{3}{*}{$\begin{array}{l}\text { (Marr et al., 2016) } \\
\text { (Marr et al., 2016) } \\
\text { (Lynn et al., 2011) } \\
\text { (Marr et al., 2016) } \\
\text { (Lynn et al., 2011) }\end{array}$} \\
\hline & RI-BMAP-28 & GIRIIPVIIPGYKKWARLIKRGLSRLGG & L. major promastigote & \\
\hline & D-BMAP-28 & GGLRSLGRKILRAWKKYGPIIVPIIRIG & L. major promastigote & \\
\hline \multirow{4}{*}{ 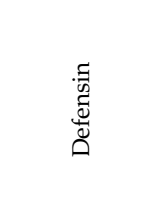 } & MBD1 & $\begin{array}{c}\text { MKTHYFLLVMICFLFSQMEPGVGILTSLGRRTDQYKCLQ } \\
\text { HGGFCLRSSCPSNTKLQGTCKPDKPNCCK }\end{array}$ & L. major & (Daneshvar et al., 2018) \\
\hline & MBD2 & $\begin{array}{l}\text { MRTLCSLLLICCLLFSYTTPAVGSLKSIGYEAELDHCHTN } \\
\text { GGYCVRAICPPSARRPGSCFPEKNPCCKYMK }\end{array}$ & L. major & (Daneshvar et al., 2018) \\
\hline & MBD3 & $\begin{array}{c}\text { MRIHYLLFAFLLVLLSPPAAFSKKI- } \\
\text { NNPVSCLRKGGRCWNR- } \\
\text { CIGNTRQIGSCGVPFLKCCKRK }\end{array}$ & L. major & (Daneshvar et al., 2018) \\
\hline & Vu-Def & MKTCENLADTYRGP & L. amazonensis & (dos Santos et al., 2010) \\
\hline
\end{tabular}


Table 1. Cont

\begin{tabular}{|c|c|c|c|c|}
\hline AMPs Family & Peptide Name & Sequence & Leishmania species & Reference \\
\hline \multirow{4}{*}{ 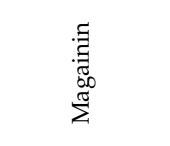 } & MG-H1 & GIKKFLHIIWKFIKAFVGEIMNS & L. donovani promastigotes & (Guerrero et al., 2004) \\
\hline & MG-H2 & IIKKFLHSIWKFGKAFVGEIMNI & L. donovani promastigotes & (Guerrero et al., 2004) \\
\hline & F5W-magainin 2 & GIGKWLHSAKKFGKAFVGEIMNS & L. donovani promastigotes & (Guerrero et al., 2004) \\
\hline & Pexiganan & GIGKFLKKAKKFGKAFVKILKK & L. major & $\begin{array}{l}\text { (Zhang et al., 2015) } \\
\text { (Kulkarni et al., 2009) }\end{array}$ \\
\hline \multirow{4}{*}{ 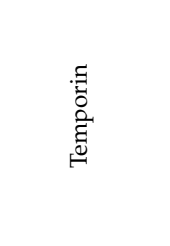 } & Temporin A & FLPLIGRVLSGIL & \multirow{4}{*}{$\begin{array}{l}\text { L. donovani promastigotes } \\
\text { L. pifanoi amastigotes } \\
\text { L. braziliensis, L. major } \\
\text { L. infantum } \\
\text { L. infantum, L. major, L. tropica, } \\
\text { L. amazonensis, and } \\
\text { L. braziliensis promastigotes } \\
\text { L. infantum axenic } \\
\text { amastigotes }\end{array}$} & (Mangoni et al., 2005) \\
\hline & Temporin B & LLPIVGNLLKSLL & & (Mangoni et al., 2005) \\
\hline & Temporin-She & FLPALAGIAGLLGKIF & & (André et al., 2020) \\
\hline & SHd & FLPAALAGIGGILGKLF & & (Mangoni et al., 2005) \\
\hline \multirow{2}{*}{ 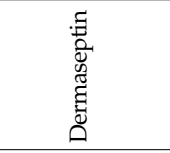 } & DS 01 & GLWSTIKQKGKEAAIAAAKAAGQAALGAL & $\begin{array}{c}\text { L. amazonensis promastigotes } \\
\text { L. panamensis }\end{array}$ & (Salay et al., 2011) \\
\hline & Dermaseptin S1 & ALWKTMLKKLGTMALHAGKAALGAAADTISQGTQ & $\begin{array}{c}\text { L. mexicana promastigotes } \\
\text { L. donovani } \\
\text { L. amazonensis amastigotes }\end{array}$ & $\begin{array}{c}\text { (Pérez-Cordero et al., 2011) } \\
\text { (Yang et al., 2019) }\end{array}$ \\
\hline \multirow{3}{*}{ 泀 } & Eumenitin & LNLKGIFKKVASLLT & L. major Promastigote & (Sabiá et al., 2019) \\
\hline & Eumenitin-F & LNLKGLFKKVASLLT & L. major Promastigote & (Sabiá et al., 2019) \\
\hline & Eumenitin R & LNLKGLIKKVASLLN & L. major Promastigote & (Sabiá et al., 2019) \\
\hline \multirow{3}{*}{ 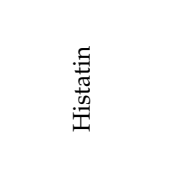 } & Hst5 & DSHAKRHHGYKRKFHEKHHSHRGY & \multirow{3}{*}{$\begin{array}{l}\text { L. donovani promastigotes } \\
\text { L. pifanoi axenic } \\
\text { L. donovani promastigotes } \\
\text { L. pifanoi axenic } \\
\text { L. donovani promastigotes } \\
\text { L. pifanoi axenic }\end{array}$} & (Luque-Ortega et al., 2008) \\
\hline & D- Hst5 & D- DSHAKRHHGYKRKFHEKHHSHRGY & & (Luque-Ortega et al., 2008) \\
\hline & Dhvar4 & KRLFKKLLFSLRKY & & (Luque-Ortega et al., 2008) \\
\hline
\end{tabular}

The general mechanisms of action of these AMPs against microorganisms are summarized in Figure 1.

In this review, we mainly describe the principal families of AMPs exhibiting a potential anti-leishmanial activity, as well as in their effectiveness against other parasites and bacteria.

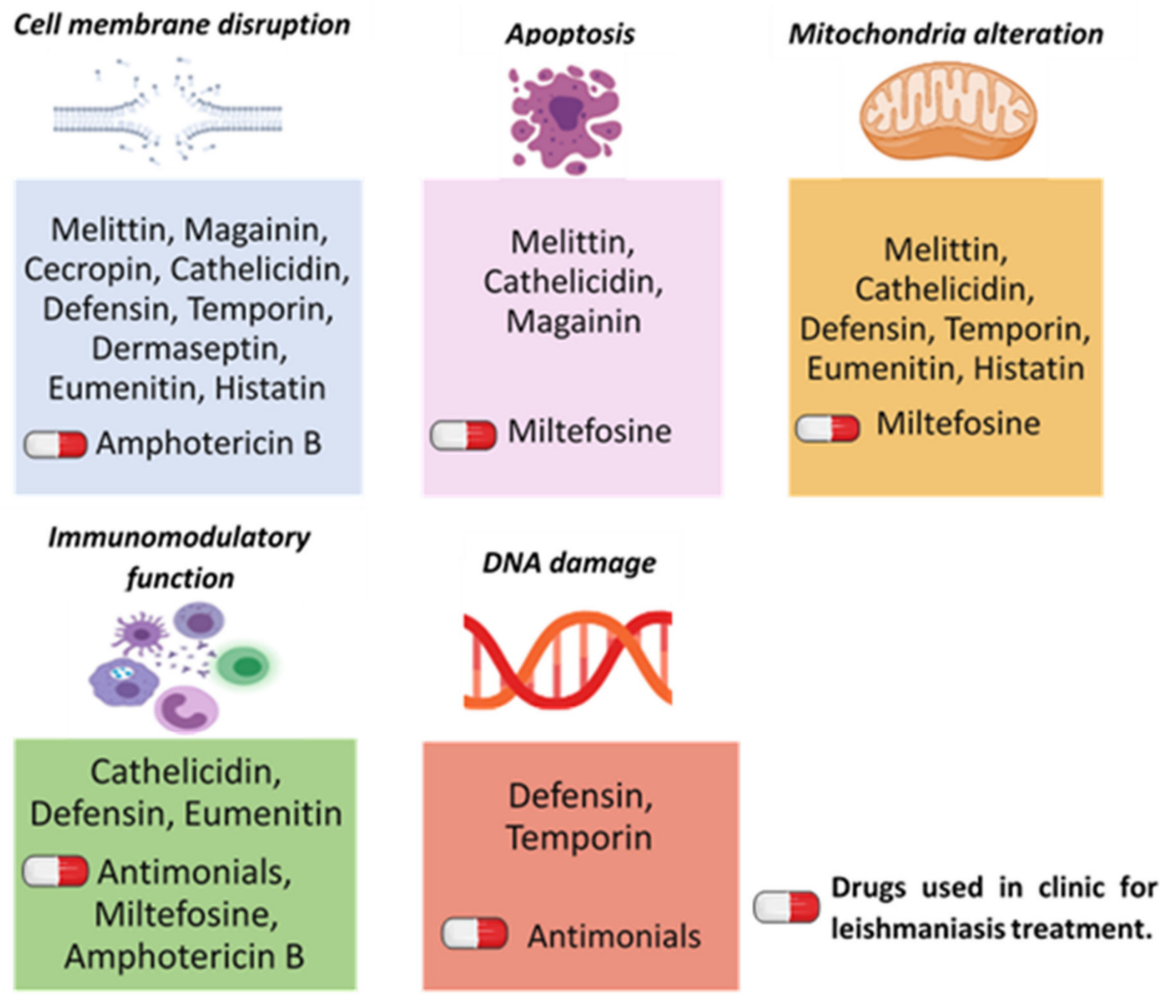

Figure 1. General mechanisms of action of the different families of AMPs with anti-leishmanial activity. Cell membrane disruption is the main mechanism of action adopted by all the described AMPs [50-59] While some of them present additional mechanisms of action (apoptosis, mitochondrial 
dysfunction, immune response modulation, and DNA damage) [60-66]. On the other hand, current drugs used in clinic for leishmaniasis treatment were found to exert similar mechanisms of action. For example, Amphotericin B principally affects the cell membrane [67] and can also modulate the immune response [68]. Miltefosine generates cell death mechanism (apoptosis) [69,70], affects the mitochondrial function [71] and the immune response [72]. Pentavalent antimonials cause DNA damage and can indirectly act by regulating the immune response $[73,74]$.

\section{Families of AMPs and Their Anti-Infectious Activities}

\subsection{Melittin}

\subsubsection{Melittin against Leishmaniasis}

Melittin is a potent cationic peptide found in the bee venom of Apis mellifera (European honey bee), and is used as an anti-inflammatory agent $[75,76]$. It is considered as the main bioactive constituent of the bee venom [77]. Melittin is a linear peptide consisting of 26 amino acid residues (H-Gly-Ile-Gly-Ala-Val-Leu-Lys-Val-Leu-Thr-Thr-Gly-Leu-ProAla-Leu-Ile-Ser-Trp-Ile-Lys-Arg-Lys-Arg-Gln-Gln-OH) (Table 1) and harbors amphiphilic properties [76] which enhance its ability to induce membrane permeabilization in both prokaryotic and eukaryotic cells [78]. Therefore, melittin displays several biological activities. Besides its haemolytic activity, melittin can also be used as anti-microbial [79], anti-viral, anti-fungal [75] and anti-tumoral agent [77]. In addition, inhibitory effects of this peptide on parasitic protozoa have been described without significant toxicity [80].

Several studies have reported the effectiveness of melittin against leishmaniasis. It was demonstrated that melittin is active on $L$. donovani promastigotes, showing an $\mathrm{IC}_{50}$ value (50\% inhibitory concentration) lower than $1.5 \mu \mathrm{M}$ [81]. Melittin was purchased from Sigma (St. Louis, MO, USA) [81]. Another study has revealed that melittin was effective on L. major and L. panamensis promastigotes, with $\mathrm{IC}_{50}$ values of $74.01 \mu \mathrm{g} / \mathrm{mL}$ and $100 \mu \mathrm{g} / \mathrm{mL}$, respectively [79]. Lastly, Pereira et al. revealed the potential of melittin against L. infantum in both promastigotes and amastigotes forms [75].

\subsubsection{Activity on Other Parasites}

Melittin has been proved to act against Trypanosoma cruzi parasite, responsible for Chagas disease. This AMP showed a lytic activity on different developmental forms of the parasite: the epimastigote (vector stage), the trypomastigote (infective non proliferative stage) and the intracellular amastigote (proliferative stage) [80]. Interestingly, melittin affected the viability of T. cruzi amastigotes at lower concentrations compared to the concentrations inducing toxicity in mammalian cells (100-fold lower) [80]. Melittin was obtained from Sigma (St. Louis, MO, USA) [80]. Furthermore, the peptide caused morphological alterations in the parasite on nuclei, mitochondria, and membrane extensions. The mechanisms of death activated by such an AMP might be apoptosis as well as autophagy [80] (Figure 1).

Moreover, new studies demonstrated that the hybrid peptide CM11, composed of melittin and another AMP called cecropin, exerts a potent killing effect against Entamoeba histolytica intestinal parasite.

The cytotoxicity of CM11 was evaluated on E. histolytica alone, and co-cultured with the human colonic carcinoma cell line (Caco-2). CM11 peptide exhibited an anti-parasitic activity of $93.7 \%$ on E. histolytica trophozoites alone, while $63.5 \%$ of trophozoites were killed in the co-culture at the same peptide concentration $(24 \mu \mathrm{g} / \mathrm{mL})$. This result suggested that the co-culture of the parasite with the host epithelial cells conferred it a higher resistance to the peptide [82]. Melittin was active against sporogenic stages of Plasmodium: in vitro assays showed that, at $50 \mu \mathrm{M}$, the peptide was able to kill $100 \%$ of $P$. berghei ookinetes following $24 \mathrm{~h}$ treatment. In vivo effect of melittin on mosquitos infected with Plasmodium parasites was also studied. Anopheles stephensi mosquitoes were fed on blood containing rodent malaria P. berghei gametocytes, while in An. gambiae mosquitoes, the feeding blood contained human malaria $P$. falciparum gametocytes both supplemented with $50 \mu \mathrm{M}$ of melittin. The compound reduced the infection and the parasite burden inside the host 
cells by $10 \%$ and $86 \%$, respectively, after an infection by P. berghei, and by $60 \%$ and $57 \%$, respectively, when cells were parasited by $P$. falciparum. Interestingly, when added to a noninfective blood meal, melittin showed no impact on mosquito longevity and fecundity [83].

\subsection{Cecropin}

\subsubsection{Cecropin and Leishmania}

Cecropins anti-microbial peptides, initially found in the hemolymph of Hyalophora cecropia, are a main part of the innate immunity of insects [84]. They are also produced naturally by other kinds of insects (Galleria mellonella, tsetse flies, Drosophila) after bacterial infections $[85,86]$. They are linear cationic peptides having a sequence of 31-37 amino acids that differ greatly depending on the species [84]. Cecropins are considered an essential family of amphipathic proteins in insects. Cecropin homologues have been detected in mammals as well, showing the high level of conservation of the non-specific (i.e., innate) immune system between insects and mammals.

Cecropin family consists of five subtypes $(A-E)$ in addition to other cecropin-like peptides, such as spodopsins papiliocins, enbocins, stomoxins, and sarcotoxins [87-91]. Regardless their potential bactericidal activity [92], cecropins have shown a promising activity against tumor cell proliferation [93], in addition to their significant anti-fungal activity [94]. Likewise, the activity of cecropins against Leishmania parasites has been explored in several studies. Cecropin A can be purchased from Peninsula Laboratories (Belmont, CA, USA) [81]. Cecropin-D (Table 1), which is Cecropin-A homologous, has shown reduction of the parasite growth of Leishmania $(V)$ panamensis promastigotes by $57 \%$ when the concentration was $100 \mu \mathrm{M}$ [86]. In another study, Cecropin-A extracted from Hyalophora and Drosophila (Table 1) was demonstrated to inhibit the Leishmania aethiopica growth (amastigotes and promastigotes), with lower concentrations against amastigotes (50\% inhibition at concentrations $\sim 0.250 \mathrm{mg} / \mathrm{mL}$ ). Interestingly, those peptides showed no hemolytic activity at the same concentrations [85]. Another study reported that cecropin-A was the most active on L. panamensis amastigotes, among three tested cecropins (cecropinA, -B, -C) isolated from the giant silkworm Hyalophora cecropia hemolymph. Interestingly, Cecropin-A was neither cytotoxic nor haemolytic at the corresponding concentrations [79].

\subsubsection{Activity on Other Parasites}

Several studies reported the anti-parasitic activity of cecropins. Cecropin-B was active against a variety of Plasmodium species when administered to its mosquito vector. When the peptide at $0.5 \mu \mathrm{g} / \mu \mathrm{L}$ of was injected into anopheline mosquitos five or more days after a Plasmodium-infected blood meal, the effect of cecropin on the development of oocysts was dramatic. Light microscopy imaging analysis showed that the peptide also induced deformation of the developing oocysts [95]. In another study, the Plasmodium vector Anopheles gambiae, was genetically modified to express the anti-microbial peptide cecropin-A. The number of oocysts was reduced by $60 \%$ in genetically-modified $A$. gambiae mosquitoes compared to non-transgenic ones, both infected with Plasmodium berghei [96]. On the other hand, the infection of the tsetse fly Glossina morsitans with Trypanosoma brucei brucei induced the synthesis of cecropin, which represented a marker of the humoral immunity [97]. Lastly, SB-37, a derivate of cecropin-B, demonstrated a lethal effect on Plasmodium falciparum and Trypanosoma cruzi parasites without cytotoxicity in host eukaryotic cells (erythrocytes and Vero cell line) [98].

\subsection{Cathelicidin}

\subsubsection{Cathelicidin and Leishmania}

Cathelicidins constitute another well-characterized AMP family with members distributed in different mammal species, including pig, cow, rabbit, and humans. Cathelicidins are cationic, amphiphilic peptides having 12-97 amino acids in length [99]. There is a wide variety of cathelicidin-derived peptides which differ in structure and activity (Table 1). Cathelicidin derivatives are generated through the proteolytic cleavage of the cathelin- 
domain, which is conserved in all the family members. This enzymatic process allows the mature $\mathrm{COOH}$-terminal anti-microbial peptide to be released [100].

Regarding properties other than anti-microbial, some members of this family were reported to possess host defense capacity, and described to induce wound healing by activating mesenchymal cells [101]. Many other activities of cathelicidin members have been observed as well. CAMP, the sole cathelicidin-type peptide identified so far in humans, is mainly detected in the cells involved in the host defense response (neutrophils, macrophages), endothelial and epithelial cells. In addition to its direct role in fighting microorganisms, CAMP could also act indirectly by regulating apoptosis, angiogenesis, cell proliferation, inflammatory reactions, cytokine release, and cell cycle arrest (Figure 1). Recently, CAMP has been described to act as anti-oncogenic agent in breast cancer [101]. Regarding cutaneous leishmaniasis (CL), a study in Ethiopian patients proved the existence of high expression of CAMP in skin lesions [102].

Moreover, recombinant cathelicidin was reported to be leishmanicidal [103]. Chathelicidin LL-37 was produced by Thermo-Fischer [103]. In another study, LL-37 peptide (Table 1), which is a cathelicidin-derived peptide obtained by the cleavage of the human cationic anti-microbial peptide-18 (hCAP-18) encoded by CAMP, demonstrated an effectiveness against leishmaniasis: LL-37 was able to decrease around $50 \%$ of the viability of the promastigotes of $L$. donovani compared to the untreated control. Furthermore, in their intramacrophage stage, $L$. donovani and L. major amastigotes were equally susceptible to LL-37 peptide [104]. Likewise, the bovine myeloid anti-microbial peptide (BMAP-28) was also studied against Leishmaniasis. BMAP-28 peptide is a cathelicidin consisting of 28 amino acids (Table 1 ) isolated from bovine neutrophils. RI-BMAP-28, L-BMAP-28, andDBMAP-28 were considerably active in vitro on Leishmania promastigotes, and the D-isoform was the most effective in the reduction of promastigote viability. Furthermore, BMAP-28 peptides have shown activity against amastigotes. Hence, RI-BMAP-28, L-BMAP-28, and D-BMAP-28, could be promising alternative treatments of leishmaniasis [105].

\subsubsection{Activity on Other Parasites}

The equine anti-microbial peptide eCATH1 was found to display a trypanocidal activity against three species of Trypanozoon parasites: T. equiperdum, T. evansi, and T. brucei brucei, responsible for animal trypanosomiasis dourine, surra, and nagana, respectively. In vitro studies showed that eCATH1 acts similarly against all trypanozoon parasites exhibiting an $\mathrm{IC}_{50}=9.5 \mu \mathrm{M}$ [106]. eCATH1 was able to modify the plasma membrane permeability inducing autophagic, necrotic cell death, or apoptosis. In addition, the disruption of the potential of the mitochondrial membrane was rapidly observed after $15 \mathrm{~min}$ of treatment with eCATH1 at its $\mathrm{IC}_{50}(=9.5 \mu \mathrm{M})$. Moreover, dramatic structural changes were reported, like membrane blebbing of organelles, cytoplasmic vacuolization, trypanosome body swelling, perturbation, and loss of microtubules of the membrane. Furthermore, the administration of eCATH1 at $10 \mathrm{mg} / \mathrm{kg}$ to T. equiperdum-infected animals delayed mouse death. In accordance with these findings, it was hypothesized that trypanosomes would be unlikely to develop resistance to eCATH1, because of the unique combination of mechanisms of action, differing from the classic membrane disruption, so common in other AMPs [106].

Within this family, LZ1, a well-studied peptide found in snakes, was shown to possess promising anti-plasmodial effects. The percentage of the asexual blood stage of $P$. falciparum parasites decreased in vitro by an average of $61 \%$ after treatment with a low concentration of LZ1. The in vivo anti-plasmodial effect of LZ1 was assessed in P. berghei infected mouse models, which displayed prolonged survival and decreased in the parasitemia rate compared to uninfected animals. Interestingly, LZ1 induced modulated the immunity of $P$. berghei infected mice by decreasing the overexpression of pro-inflammatory factors (IFN- $\gamma$, IL-6, TNF- $\alpha$,); thus, it attenuated liver damage resulting from malarial infection. An additional mechanism of LZ1 was found to selectively lower the synthesis of ATP in infected RBC, by the inhibition of pyruvate kinase function [107]. 


\subsection{Defensin}

\subsubsection{Defensin and Leishmania}

Defensins are part of the first groups of anti-microbial peptides identified in mammalian organisms. Like the other AMPs described so far, they are characterized by a conserved six-cysteine signature, and are classified into three sub-groups, $\alpha, \beta$, and $\theta$ [108]. Defensins are derived from human beings and other organisms $[109,110]$. In humans, they are a key element in the innate immunity, playing a crucial role in host defense against microbial infections. In addition, defensins are an important component of acquired immunity, since they can induce the migration of different immune cells (mast cells, T-lymphocytes, dendritic cells, and monocytes) to the infection site while enhancing macrophage-mediated phagocytosis [111] (Figure 1). Notably, defensin-like peptides were also found in plants. Whereas, human defensins consist of 29-35 amino acids [109], their plant counterparts consist of 45-54 amino acids [112].

Defensins exhibit a wide variety of anti-microbial effects, such as anti-bacterial $[109,113]$, anti-fungal [110,114,115], anti-viral [116,117], and anti-leishmanial activities. A recent study demonstrated that mouse beta defensins mBD1, mBD2, and mBD3 (Table 1) were upregulated in C57BL/ 6 mice, a mouse strain well-known for its resistance to Leishmania infection. Insensitivity of C57BL/ 6 mice to Leishmania may also be the consequence of additional events of immune system activation. In this respect, it was reported that CL by L. major parasites induced secretion of interleukin (IL)-12 by macrophages. In turn, these cells induced the expression of different cytokines, like INF- $\gamma$ by T lymphocyte cells, leading to macrophage activation and the killing of the intramacrophage form of the parasite [111] (Figure 1).

Due to the important role of defensins in the resistance of plants to pathogen infections [118], plant defensins were classified as plant pathogenesis-related (PR) proteins within the PR-12 group [112]. Vigna unguiculata defensin (Vu-Def) (Table 1), a defensin of plant origin, was found to be effective against L. amazonensis. Testing of progressively shortened variants of Vu-Def allowed the identification of the key domain implicated in the anti-microbial activity of the peptide, designated as $\gamma$-core. This domain preserved the whole peptide biological activity and was identified as a conserved region formed by a few amino-acid residues. Notably, plant defensins have shown no toxicity on mammal cells [112].

\subsubsection{Activity on Other Parasites}

Human defensin $\alpha-1$ was reported to have trypanocidal effect on T. cruzi. The peptide displayed killing effects on amastigotes and trypomastigotes (at 3.7-35 $\mu \mathrm{M}$ ). Human defensin $\alpha-1$ acts by generating pores on the membrane of the trypomastigote, besides, it induces the fragmentation of their mitochondrial and nuclear DNA (Figure 1). Interestingly, the infectivity of trypomastigotes in human epithelial cell line (HeLa cells) was reduced after the pretreatment of the parasites with a sublethal dose of defensin $\alpha-1$ anti-microbial peptide [18].

Notably, defensins from the European tick vector Ixodes ricinus exerted an antimicrobial activity against $P$. falciparum which was conserved through evolution. Briefly, the sequence of the common defensin ancestor shared by scorpions and ticks (so-called Defensin Ancestor STiDA), was synthesized and tested against P. faliciparum, and its antimicrobial activity was compared with that of extant ticks' defensins. Interestingly, in vitro, STiDA significantly inhibited the parasite growth with a potency similar to that of extant tick defensins [119]. Similarly, I. ricinus defensins were reported to have anti-plasmodial activity against $P$. chabaudi in mice. Defensins considerably reduced the parasitemia $1 \mathrm{~h}$ and $12 \mathrm{~h}$ after their administration at a dose of $120 \mu \mathrm{L}$ of $1 \mathrm{mg} / \mathrm{mL}$ solution [120].

Human $\beta$-defensin-2 (HBD2), from intestinal epithelial cells (IEC), was active against Toxoplasma gondii (type I, II, and III). Pretreatments of parasites with synthetic HBD2 at $25 \mu \mathrm{M}$ and $50 \mu \mathrm{M}$ concentrations significantly decreased their infectivity. 
Nevertheless, the high-virulence T. gondii (type I) repressed the early expression of HBD2 gene in IEC, while the low-virulence strains (type II and III) strongly stimulated it. These outcomes proved the role of human $\beta$-defensin- 2 as an anti-microbial agent in innate immune response against $T$. gondii [121].

A further study proved the parasiticidal effect of human $\beta$-defensin- 1 and -2 against Cryptosporidium paroum parasites by decreasing their infectivity and viability. These AMPs lead to the disruption of the membrane, reducing the osmoregulation and, finally, inducing cell death [122].

\subsection{Magainin}

\subsubsection{Magainin and Leishmania}

Another well-studied family of $\alpha$-helical peptides with similar mechanism of action to that of melittin are the magainins [123]. Magainin is a 23-residue peptide synthesized by the African clawed frog (Xenopus laevis) [124]. As other AMPs, magainin peptides exert their activity through insertion into cell membranes after interacting with negatively charged phospholipids and finally leading to cell lysis [125,126] (Figure 1). Magainins present low toxicity towards red blood cell membranes [127] and these peptides showed activity against microbes and were effective as anti-tumor agents [128,129].

Different magainins have been reported to be active on Leishmania protozoan. Among them, two hydrophobic magainin-2 analogues, MG-H1 and MG-H2, and their parental peptide, F5W-magainin-2 (Table 1), were tested on L. donovani. The results showed that the three peptides inhibited $L$. donovani promastigotes proliferation at micromolar concentrations, MG-H2 exhibiting the most potent activity [130]. Similar to other leishmanicidal membrane-disrupting peptides (cecropin-A-melittin hybrids and dermaseptins), the mechanism of action of the aforementioned magainins (magainin-2 analogues, MG-H1 and MG-H2) was dependent on parasite membrane disruption followed by induction of a fast bioenergetics collapse [130] (Figure 1). More recently, pexiganan peptide (Table 1), a synthetic magainin analog rich in lysine, has revealed apoptotic effect in Leishmania promastigotes [131] (Figure 1).

\subsubsection{Activity on Other Parasites}

Magainin-2, a vertebrate polycationic peptide, exhibits cytotoxic effects against Cryptosporidium parvum sporozoites. After 20- and 60-min exposure to the AMP, at 100 and $10 \mu \mathrm{g} / \mathrm{mL}$, respectively, the percentage of sporozoites viability decreased significantly and reached $9.7 \%$. In contrast, on C. parvum oocysts, magainin-2 did not completely reduce the oocyst growth, and the percentage of viability remained above $65 \%$ after $180 \mathrm{~min}$ of exposure to a high peptide concentration $(100 \mu \mathrm{g} / \mathrm{mL})$. Concerning the mode of action of magainin-2, it has been hypothesized that the molecule could alter the apical complex of the sporozoite containing the ligands involved in the attachment and invasion of the host epithelial cells. In contrast, inside the oocysts, sporozoites are protected by a thick wall, which may explain the low effect of the peptide against non-excysted organisms [132].

\subsection{Temporin}

\subsubsection{Temporin and Leishmania}

Temporins are natural host defense AMPs isolated from frog's skin and consist of 10 to 17 amino acids [133]. They belong to $\alpha$-helical AMPs with highly cationic and amphipathic properties that allow them to target different pathogens, including bacteria $[134,135]$, viruses [136], filamentous fungi [137,138], and parasites [139]. These same properties are also responsible for their significant hemolytic activity and cytotoxicity [140]. So far, 130 peptides of this family have been identified. Temporin-A (TA), temporin-B (TB), and temporin-L (TL) have been largely studied since they are highly active against several microorganisms.

Both TA and TB (Table 1) were reported to display activity on L. donovani promastigotes and L. pifanoi amastigotes [141]. Their leishmanicidal action is favored by their capacity 
to induce membrane permeation causing severe damage to the parasite membrane [141] (Figure 1). Likewise, temporin SHd (Table 1) showed effective activity against promastigote forms of numerous Leishmania (L. infantum, L. major, L. tropica, L. amazonensis, and L. braziliensis) with similar mechanism of action. SHd was also active against L. infatum axenic amastigotes [141].

Recently, the anti-microbial activity of the peptide temporin-SHe (Table 1), a temporin$\mathrm{SH}$ paralog from the Sahara frog (Pelophylax saharicus) was investigated [142]. TemporinSHe was active on L. braziliensis and L. major promastigotes at 10.5 and $11.6 \mu \mathrm{M}$, respectively. It was highly potent against $L$. infantum as well, at lower $\mathrm{IC}_{50}$ value $(4.6 \mu \mathrm{M})$.

\subsubsection{Activity on Other Parasites}

Temporizin (an artificial hybrid peptide containing the $\mathrm{N}$-terminal region of temporin A) and Temporizin-1 (a modification of Temporizin) showed promising activity against Trypanosoma cruzi. Flow cytometry assay revealed that temporizin- 1 eliminated $57 \%$ of the parasites while temporizin killed $65 \%$. The $\mathrm{EC}_{50}$ values obtained by the MTT assay were $887 \mathrm{ng} / \mathrm{mL}$ for temporizin- 1 and $849 \mathrm{ng} / \mathrm{mL}$ for temporizin. Interestingly, both peptides induced intracellular alterations like chromatin condensation and mitochondrial cristae disorder (Figure 1). However, temporizin and temporizin-1 seemed not to affect T. cruzi cytoplasmic membrane, suggesting their ability to modify the fluidity of trypanosome cytoplasmic membrane [143].

Among temporins-SH isolated from the North African ranid frog Pelophylax saharicus, $\mathrm{SHa}$ has emerged as a potent AMP. SHa and its analog $\left[\mathrm{K}^{3}\right] \mathrm{SH}$ a were tested on T. brucei gambiense and T. cruzi. SHa and $\left[\mathrm{K}^{3}\right] \mathrm{SHa}$ exerted trypanocidal effect at low concentrations $\left(\mathrm{IC}_{50}\right.$ $\sim 10-17 \mu \mathrm{M})$. Morphological changes were observed in T. cruzi epimastigotes treated with $5 \mu \mathrm{M}$ [K3]SHa during half an hour. The peptide damaged the cell body and the flagellum, modifying cell morphology, and indicating that temporin acts through a membranolytic mechanism [139] (Figure 1).

\subsection{Dermaseptin}

\subsubsection{Dermaseptin against Leishmaniasis}

Dermaseptins are natural polycationic peptides secreted by the skin of amphibians as a defense strategy against microbes. They are typically constituted of 27-34 amino acids that greatly vary from one peptide to another. However, they all share a cationic amphipathic nature. Dermaseptins are lethal at very low doses against several microorganisms (bacteria, fungi, parasites, yeast, and enveloped viruses). Dermaseptins are not toxic to mammalian cells, except for dermaseptin $\mathrm{S} 4$ which displays potent hemolytic and anti-protozoan effects [144]. The first described member of the family, dermaseptin S1 (Table 1), was reported to have anti-leishmanial activity against L. panamensis [79]. Moreover, Dermaseptins S1-S5 was lethal against L. mexicana in its promastigote form at low concentrations [79]. They act by inducing cell membrane disruption leading to parasite death [145] (Figure 1).

Dermaseptin 01 (DS 01, Table 1), a synthetic dermaseptin peptide, was also reported to be active against $L$. amazonensis in the promastigote form [146,147].

More recently, encapsulation of dermaseptin S1 in Cry3Aa crystals, was shown to enhance its effectiveness on intracellular Leishmania parasites (L. amazonensis and L. donovani) [148]. Dermaseptin DS1 peptide was purchased from Pepmic Company (Suzhou, China) [148].

\subsubsection{Activity on Other Parasites}

DS 01 was reported to be active against Schistosoma mansoni helminth, responsible for human schistosomiasis. At $100 \mu \mathrm{g} / \mathrm{mL}$, DS 01 decreased the worm motility and killed all worms within $48 \mathrm{~h}$. Furthermore, DS 01 has shown an effect on the reproductive fitness of adult worms. This deleterious effect is associated with shape changes on the tegument of S. mansoni, a critical organelle during the infection and survival in the host [149]. In another study, DS 01 was found to have anti-Trypanosoma cruzi effect. At $6 \mu \mathrm{M}$, this AMP reduced the protozoan cell population to a non-detectable level after $2 \mathrm{~h}$ of incubation. DS 
01 exerted its trymanocidal activity by inducing the membrane disruption and cell leakage. On the other hand, DS 01 was not hemolytic against red blood cells, suggesting that it could be used in systemic therapy [150]. Phylloseptins, another family of dermaseptins discovered in the skin of Phyllomedusa, also showed anti-Trypanosoma cruzi activity. Among this family, PS-4 and PS-5 were highly effective on T. cruzi trypomastigotes $\left(\mathrm{IC}_{50}=5.1\right.$ and $4.9 \mu \mathrm{M}$, respectively) [151].

\subsection{Eumenitin and Leishmania}

Eumenitin is a recently identified anti-microbial peptide, discovered in 2006 by Konno et al. [65]. These investigators isolated eumenitin from the venom of Eumenes rubronotatus. Eumenitin is composed of 15 amino-acids (LNLKGIFKKVASLLT) (Table 1) and is predicted to adopt a linear $\alpha$-helical structure [65].

This AMP has shown activity against L. major promastigotes. Furthermore, a study carried out by Rangel et al. reported that both peptides, eumenitin-F (LNLKGLFKKVASLLT) isolated from Eumenes fraterculus and eumenitin-R (LNLKGLIKKVASLLN) isolated from E. rubrofemoratus (Table 1), displayed anti-leishmanial activity against promastigotes of L. major (Table 1) [152,153].

\subsection{Histatin Effect on Leishmania}

Histatins are human oral anti-microbial peptides secreted by the salivary glands into the saliva and related to immunity [154]. The histatin family contains 12 small histidine-rich cationic AMPs with the most abundant ones being histatin 1, 3, and 5 [155]. The other histatins are known to be proteolytic derivatives of histatins 1 and 3 [156]. Histatins are effective on several microbes. Regarding their anti-leishmaniasis activity, only Hst5, its D-enantiomer and its synthetic analog Dhvar4 (Table 1) have been studied on L. donovani promastigotes and L. pifanoi amastigotes. Hst5 was active on Leishmania at micromolar concentrations (lethal doses 50 7.3 $\mu \mathrm{M}$ on promastigotes and $\sim 14.4 \mu \mathrm{M}$ on amastigotes) [157]. D- Hst5 and Dhvar4 were more active on both parasite forms than Hst-5 [157].

\section{Conclusions and Future Perspectives}

As shown above, several lines of evidence show that AMPs are very promising antiparasitic agents: (a) they are rapidly lethal against Leishmania and other parasites at doses comparable to those of current treatments; (b) they have a broad spectrum of bactericidal activity, a property that makes them very valuable for the treatment of polymicrobial infections; (c) the emergence of resistance to AMPs is unlikely, since these agents target cell structures that are essential for the organism and very conserved at the molecular level; (d) some of them have immunomodulating properties that enhance pathogen elimination; (e) their biological activity can be repeatedly improved by conducting studies of structureactivity relationship (SAR); and (f) a particularly promising field of research with AMPs involves the development of therapies based on combinations of AMPs with conventional anti-parasitic agents.

In spite of all these attractive features, AMPs also have limitations that may restrict their therapeutic use. First, the activity of many of these peptides is reduced or even abrogated in the presence of physiological concentrations of salts or other biological compounds. In addition, some AMPs are degraded by serum proteases, and this effect greatly decreases their in vivo half-life. Finally, due to their unspecific mechanism of action, these agents exhibit some level of cytotoxicity close to their therapeutic concentration [158]. Nevertheless, for the topical treatment of skin diseases (e.g., cutaneous leishmaniasis), these drawbacks should not hinder at all the development of AMP-based treatments in the near future.

Because of the limitations of the existing anti-parasitic treatments, the reported features of AMPs make them promising candidates to replace current available therapies. Some pharmaceutical companies are developing anti-bacterial and anti-fungal drugs based on natural peptides and it is very likely for such peptides to progress into clinical development. 
Specifically, in the case of cutaneous leishmaniasis, we expect AMP-based treatments to get approval for clinical use in very few years.

Author Contributions: Conceptualization, P.A.N. and R.E.-D.; Writing—original draft preparation, R.E.-D., H.S. and Z.D.; Writing-review and editing, F.A.-S., G.G.-G., K.B., G.M.d.T., R.E.-D. and P.A.N.; Supervision, P.A.N.; Project administration, P.A.N. All authors have read and agreed to the published version of the manuscript.

Funding: This research was funded by the Spanish ministry MINECO (project PID2020-112713RBC21). PN thanks Fundación La Caixa (LCF/PR/PR13/11080005), Fundación Caja Navarra, Fundación Roviralta, Ubesol, Government of Navarre, Laser Ebro, Inversiones Garcilaso de la Vega and COST Actions CA18217 (ENOVAT) and CA18218, and EU Project unCoVer (DLV-101016216) for their support. GMT work was supported by University of Navarra (PIUNA PROJECT P2015-14) in Spain and co-funded by the Lebanese University and the Lebanese National Council for Scientific Research (fund number: 1-10-2017). A PhD scholarship was granted by the Islamic Center Association for Guidance and Higher Education (CIOES) to H.S. and R.E.-D.

Institutional Review Board Statement: Not applicable.

Informed Consent Statement: Not applicable.

Data Availability Statement: Not applicable.

Acknowledgments: Icons in Figure 1 were created with BioRender.com.

Conflicts of Interest: The authors declare no conflict of interest.

\section{References}

1. Bahar, A.A.; Ren, D. Antimicrobial peptides. Pharmacy 2013, 6, 1543-1575. [CrossRef] [PubMed]

2. Mwangi, J.; Hao, X.; Lai, R.; Zhang, Z.Y. Antimicrobial peptides: New hope in the war against multidrug resistance. Zool Res. 2019, 40, 488-505. [CrossRef] [PubMed]

3. Pasupuleti, M.; Schmidtchen, A.; Malmsten, M. Antimicrobial peptides: Key components of the innate immune system. Crit. Rev. Biotechno.l 2012, 32, 143-171. [CrossRef] [PubMed]

4. Zasloff, M. Antimicrobial peptides of multicellular organisms. Nature 2002, 415, 389-395. [CrossRef]

5. Hilchie, A.L.; Wuerth, K.; Hancock, R.E.W. Immune modulation by multifaceted cationic host defense (antimicrobial) peptides. Nat. Chem. Biol. 2013, 9, 761-768. [CrossRef]

6. Kumar, P.; Kizhakkedathu, J.N.; Straus, S.K. Antimicrobial peptides: Diversity, mechanism of action and strategies to improve the activity and biocompatibility in vivo. Biomolecules 2018, 8, 4. [CrossRef]

7. Teixeira, M.C.; Carbone, C.; Sousa, M.C.; Espina, M.; Garcia, M.L.; Sanchez-Lopez, E.; Souto, E.B. Nanomedicines for the delivery of antimicrobial peptides (Amps). Nanomaterials 2020, 10, 560. [CrossRef]

8. Wang, G.; Li, X.; Wang, Z. APD3: The antimicrobial peptide database as a tool for research and education. Nucleic Acids Res. 2016, 44, D1087-D1093. [CrossRef]

9. Wang, G.; Li, X.; Wang, Z. APD2: The updated antimicrobial peptide database and its application in peptide design. Nucleic Acids Res. 2009, 37, D933-D937. [CrossRef]

10. Wang, Z.; Wang, G. APD: The Antimicrobial Peptide Database. Nucleic Acids Res. 2004, 32, D590-D592. [CrossRef]

11. Thomas, S.; Karnik, S.; Barai, R.S.; Jayaraman, V.K.; Idicula-Thomas, S. CAMP: A useful resource for research on antimicrobial peptides. Nucleic Acids Res. 2010, 38, D774-D780. [CrossRef]

12. Bulet, P.; Hetru, C.; Dimarcq, J.-L.; Hoffmann, D. Antimicrobial peptides in insects; structure and function. Dev. Comp. Immunol. 1999, 23, 329-344. [CrossRef]

13. Agerberth, B.; Charo, J.; Werr, J.; Olsson, B.; Idali, F.; Lindbom, L.; Kiessling, R.; Joörnvall, H.; Wigzell, H.; Gudmundsson, G.H. The human antimicrobial and chemotactic peptides LL-37 and $\alpha$-defensins are expressed by specific lymphocyte and monocyte populations. Blood 2000, 96, 3086-3093. [CrossRef]

14. Sørensen, O.; Cowland, J.B.; Askaa, J.; Borregaard, N. An ELISA for hCAP-18, the cathelicidin present in human neutrophils and plasma. J. Immunol. Methods 1997, 206, 53-59. [CrossRef]

15. Simmaco, M.; Mignogna, G.; Barra, D. Antimicrobial peptides from amphibian skin: What do they tell us? Pept. Sci. 1998, 47, 435-450. [CrossRef]

16. Bals, R.; Wang, X.; Zasloff, M.; Wilson, J.M. The peptide antibiotic LL-37/hCAP-18 is expressed in epithelia of the human lung where it has broad antimicrobial activity at the airway surface. Proc. Natl. Acad. Sci. USA 1998, 95, 9541-9546. [CrossRef]

17. Ma, Y.; Liu, C.; Liu, X.; Wu, J.; Yang, H.; Wang, Y.; Li, J.; Yu, H.; Lai, R. Peptidomics and genomics analysis of novel antimicrobial peptides from the frog, Rana nigrovittata. Genomics 2010, 95, 66-71. [CrossRef]

18. Oppenheim, J.J.; Biragyn, A.; Kwak, L.W.; Yang, D. Roles of antimicrobial peptides such as defensins in innate and adaptive immunity. Ann. Rheum. Dis. 2003, 62, ii17-ii21. [CrossRef] 
19. Madison, M.N.; Kleshchenko, Y.Y.; Nde, P.N.; Simmons, K.J.; Lima, M.F.; Villalta, F. Human defensin $\alpha-1$ causes Trypanosoma cruzi membrane pore formation and induces DNA fragmentation, which leads to trypanosome destruction. Infect. Immun. 2007, 75, 4780-4791. [CrossRef]

20. Yeaman, M.R.; Yount, N.Y. Mechanisms of antimicrobial peptide action and resistance. Pharmacol. Rev. 2003, 55, 27-55. [CrossRef]

21. Bals, R.; Wilson, J.M. Cathelicidins-A family of multifunctional antimicrobial peptides. Cell. Mol. Life Sci. 2003, 60, 711-720. [CrossRef]

22. Wade, J.; Lin, F.; Hossain, M.; Dawson, R. Chemical synthesis and biological evaluation of an antimicrobial peptide gonococcal growth inhibitor. Amino Acids 2012, 43, 2279-2283. [CrossRef]

23. Papo, N.; Oren, Z.; Pag, U.; Sahl, H.-G.; Shai, Y. The Consequence of Sequence Alteration of an Amphipathic $\alpha$-Helical Antimicrobial Peptide and Its Diastereomers. J. Biol. Chem. 2002, 277, 33913-33921. [CrossRef]

24. Rashid, R.; Veleba, M.; Kline, K.A. Focal Targeting of the Bacterial Envelope by Antimicrobial Peptides. Front. Cell Dev. Biol. 2016, 4, 55. [CrossRef]

25. Shagaghi, N.; Palombo, E.A.; Clayton, A.H.A.; Bhave, M. Antimicrobial peptides: Biochemical determinants of activity and biophysical techniques of elucidating their functionality. World J. Microbiol. Biotechnol. 2018, 34, 1-13. [CrossRef]

26. World Health Organization. Antimicrobial Resistance. Global Report on Surveillance; World Health Organization: Geneva, Switzerland, 2014; pp. 12-28.

27. Batoni, G.; Maisetta, G.; Brancatisano, F.L.; Esin, S.; Campa, M. Use of antimicrobial peptides against microbial biofilms: Advantages and limits. Curr. Med. Chem. 2011, 18, 256-279. [CrossRef]

28. Xu, W.; Zhu, X.; Tan, T.; Li, W.; Shan, A. Design of Embedded-Hybrid Antimicrobial Peptides with Enhanced Cell Selectivity and Anti-Biofilm Activity. PLoS ONE 2014, 9, e098935. [CrossRef]

29. De La Fuente-Núñez, C.; Cardoso, M.H.; De Souza Cândido, E.; Franco, O.L.; Hancock, R.E.W. Synthetic antibiofilm peptides. Biochim. Biophys. Acta 2016, 1858, 1061-1069. [CrossRef] [PubMed]

30. Oliveira, M.; Gomes-Alves, A.G.; Sousa, C.; Mirta Marani, M.; Plácido, A.; Vale, N.; Delerue-Matos, C.; Gameiro, P.; Kückelhaus, S.A.S.; Tomas, A.M.; et al. Ocellatin-PT antimicrobial peptides: High-resolution microscopy studies in antileishmania models and interactions with mimetic membrane systems. Biopolymers 2016, 105, 873-886. [CrossRef] [PubMed]

31. Karunaweera, N.D.; Ferreira, M.U. Leishmaniasis: Current challenges and prospects for elimination with special focus on the South Asian region. Parasitology 2018, 145, 425-429. [CrossRef] [PubMed]

32. World Health Organization. Leishmaniasis 2018 (22nd December); World Health Organization: Geneva, Switzerland, 2018. Available online: http:/ / www.who.int/mediacentre/factsheets/fs375/en/ (accessed on September 2020).

33. Nimsarkar, P.; Ingale, P.; Singh, S. Systems Studies Uncover miR-146a as a Target in Leishmania major Infection Model. ACS Omega 2020, 5, 12516-12526. [CrossRef]

34. Sunter, J.; Gull, K. Shape, form, function and Leishmania pathogenicity: From textbook descriptions to biological understanding. Open Biol. 2017, 7, 170165. [CrossRef]

35. World Health Organization. Control of the leishmaniases. Report of a Meeting of the WHO Expert Committee on the Control of Leishmaniases, Geneva, Switzerland, 22-26 March 2010.

36. Lewis, D.J. Phlebotomid Sandflies. Bull World Health Organ. 1971, 44, 535-551.

37. Meinecke, C.K.; Schottelius, J.; Oskam, L.; Fleischer, B. Congenital transmission of visceral leishmaniasis (Kala Azar) from an asymptomatic mother to her child. Pediatrics 1999, 104, e65. [CrossRef]

38. Cruz, I.; Morales, M.A.; Noguer, I.; Rodríguez, A.; Alvar, J. Leishmania in discarded syringes from intravenous drug users. Lancet 2002, 359, 1124-1125. [CrossRef]

39. Cohen, C.; Corazza, F.; De Mol, P.; Brasseur, D. Leishmaniasis acquired in Belgium. Lancet (Lond. England) 1991, $338,128$. [CrossRef]

40. Reithinger, R.; Dujardin, J.-C.; Louzir, H.; Pirmez, C.; Alexander, B.; Brooker, S. Cutaneous leishmaniasis. Lancet. Infect. Dis. 2007, 7, 581-596. [CrossRef]

41. Blum, J.; Lockwood, D.N.J.; Visser, L.; Harms, G.; Bailey, M.S.; Caumes, E.; Clerinx, J.; van Thiel, P.P.A.M.; Morizot, G.; Hatz, C.; et al Local or systemic treatment for New World cutaneous leishmaniasis? Re-evaluating the evidence for the risk of mucosal leishmaniasis. Int. Health 2012, 4, 153-163. [CrossRef]

42. Oliveira, L.F.; Schubach, A.O.; Martins, M.M.; Passos, S.L.; Oliveira, R.V.; Marzochi, M.C.; Andrade, C.A. Systematic review of the adverse effects of cutaneous leishmaniasis treatment in the New World. Acta Trop. 2011, 118, 87-96. [CrossRef]

43. Wortmann, G.; Zapor, M.; Ressner, R.; Fraser, S.; Hartzell, J.; Pierson, J.; Weintrob, A.; Magill, A. Lipsosomal amphotericin B for treatment of cutaneous leishmaniasis. Am. J. Trop. Med. Hyg. 2010, 83, 1028-1033. [CrossRef]

44. Vacchina, P.; Morales, M.A. In vitro screening test using Leishmania promastigotes stably expressing mCherry protein. Antimicrob. Agents Chemother. 2014, 58, 1825-1828. [CrossRef]

45. Pace, D. Leishmaniasis. J. Infect. 2014, 69, S10-S18. [CrossRef]

46. Fernández-Rubio, C.; Larrea, E.; Guerrero, J.P.; Herrero, E.S.; Gamboa, I.; Berrio, C.; Plano, D.; Amin, S.; Sharma, A.K.; Nguewa, P.A. Leishmanicidal activity of isoselenocyanate derivatives. Antimicrob. Agents Chemother. 2019, 63, e00904-18. [CrossRef]

47. Ibanez, E.; Agliano, A.; Prior, C.; Nguewa, P.; Redrado, M.; Gonzalez-Zubeldia, I.; Plano, D.; Palop, J.A.; Sanmartin, C.; Calvo, A. The Quinoline Imidoselenocarbamate EI201 Blocks the AKT/mTOR Pathway and Targets Cancer Stem Cells Leading to a Strong Antitumor Activity. Curr. Med. Chem. 2012, 19, 3031-3043. [CrossRef] 
48. Fernández-rubio, C.; Campbell, D.; Vacas, A.; Ibañez, E.; Moreno, E.; Espuelas, S. Leishmanicidal Activities of Novel MethylselenoImidocarbamates. Antimicrob. Agents Chemother. 2015, 59, 5705-5713. [CrossRef]

49. Puig-Rigall, J.; Fernández-Rubio, C.; González-Benito, J.; Houston, J.E.; Radulescu, A.; Nguewa, P.; González-Gaitano, G. Structural characterization by scattering and spectroscopic methods and biological evaluation of polymeric micelles of poloxamines and TPGS as nanocarriers for miltefosine delivery. Int. J. Pharm. 2020, 578, 119057. [CrossRef]

50. Sepehri, A.; PeBenito, L.; Pino-Angeles, A.; Lazaridis, T. Membrane Pore Formation by Melittin Derivatives. Biophys. J. 2020, 118, 234a. [CrossRef]

51. Scheenstra, M.R.; van den Belt, M.; Tjeerdsma-van Bokhoven, J.L.M.; Schneider, V.A.F.; Ordonez, S.R.; van Dijk, A.; Veldhuizen, E.J.A.; Haagsman, H.P. Cathelicidins PMAP-36, LL-37 and CATH-2 are similar peptides with different modes of action. Sci. Rep. 2019, 9, 1-12. [CrossRef]

52. Coorens, M.; Schneider, V.A.F.; de Groot, A.M.; van Dijk, A.; Meijerink, M.; Wells, J.M.; Scheenstra, M.R.; Veldhuizen, E.J.A.; Haagsman, H.P. Cathelicidins Inhibit Escherichia coli-Induced TLR2 and TLR4 Activation in a Viability-Dependent Manner. J. Immunol. 2017, 199, 1418-1428. [CrossRef]

53. Kvansakul, M.; Lay, F.T.; Adda, C.G.; Veneer, P.K.; Baxter, A.A.; Phan, T.K.; Poon, I.K.H.; Hulett, M.D. Binding of phosphatidic acid by NsD7 mediates the formation of helical defensin-lipid oligomeric assemblies and membrane permeabilization. Proc. Natl. Acad. Sci. USA 2016, 113, 11202-11207. [CrossRef]

54. Järvå, M.; Lay, F.T.; Phan, T.K.; Humble, C.; Poon, I.K.H.; Bleackley, M.R.; Anderson, M.A.; Hulett, M.D.; Kvansakul, M. X-ray structure of a carpet-like antimicrobial defensin-phospholipid membrane disruption complex. Nat. Commun. 2018, 9, 1-10. [CrossRef] [PubMed]

55. Järvå, M.; Phan, T.K.; Lay, F.T.; Caria, S.; Kvansakul, M.; Hulett, M.D. Human $\beta$-defensin 2 kills Candida albicans through phosphatidylinositol 4,5-bisphosphate-mediated membrane permeabilization. Sci. Adv. 2018, 4, eaat0979. [CrossRef] [PubMed]

56. Farrotti, A.; Conflitti, P.; Srivastava, S.; Ghosh, J.; Palleschi, A.; Stella, L.; Bocchinfuso, G. Molecular Dynamics Simulations of the Host Defense Peptide Temporin L and Its Q3K Derivative: An Atomic Level View from Aggregation in Water to Bilayer Perturbation. Molecules 2017, 22, 1235. [CrossRef] [PubMed]

57. Eggimann, G.; Sweeney, K.; Bolt, H.; Rozatian, N.; Cobb, S.; Denny, P. The Role of Phosphoglycans in the Susceptibility of Leishmania mexicana to the Temporin Family of Anti-Microbial Peptides. Molecules 2015, 20, 2775-2785. [CrossRef]

58. Arcisio-Miranda, M.; dos Santos Cabrera, M.P.; Konno, K.; Rangel, M.; Procopio, J. Effects of the cationic antimicrobial peptide eumenitin from the venom of solitary wasp Eumenes rubronotatus in planar lipid bilayers: Surface charge and pore formation activity. Toxicon 2008, 51, 736-745. [CrossRef]

59. Jang, W.S.; Bajwa, J.S.; Sun, J.N.; Edgerton, M. Salivary histatin 5 internalization by translocation, but not endocytosis, is required for fungicidal activity in Candida albicans. Mol. Microbiol. 2010, 77, 354-370. [CrossRef]

60. Oñate-Garzón, J.; Manrique-Moreno, M.; Trier, S.; Leidy, C.; Torres, R.; Patiño, E. Antimicrobial activity and interactions of cationic peptides derived from Galleria mellonella cecropin D-like peptide with model membranes. J. Antibiot. 2017, 70, 238-245. [CrossRef]

61. Peng, J.; Wu, Z.; Liu, W.; Long, H.; Zhu, G.; Guo, G.; Wu, J. Antimicrobial functional divergence of the cecropin antibacterial peptide gene family in Musca domestica. Parasites Vectors 2019, 12, 537. [CrossRef]

62. Silvestro, L.; Weiser, J.N.; Axelsen, P.H.; Gupta, K.; Weiser, J.H.; Axelsen, P.H. Antibacterial and Antimembrane Activities of Cecropin A in Escherichia coli. Antimicrob. Agents Chemother. 2000, 44, 602-607. [CrossRef]

63. Amini, A.; Raheem, S.; Steiner, A.; Deeba, F.; Ahmad, Z. Insect venom peptides as potent inhibitors of Escherichia coli ATP synthase. Int. J. Biol. Macromol. 2020, 150, 23-30. [CrossRef]

64. Dos Santos Cabrera, M.P.; Arcisio-Miranda, M.; da Costa, L.C.; de Souza, B.M.; Broggio Costa, S.T.; Palma, M.S.; Ruggiero Neto, J.; Procopio, J. Interactions of mast cell degranulating peptides with model membranes: A comparative biophysical study. Arch. Biochem. Biophys. 2009, 486, 1-11. [CrossRef]

65. Konno, K.; Hisada, M.; Naoki, H.; Itagaki, Y.; Fontana, R.; Rangel, M.; Oliveira, J.S.; Dos santos Cabrera, M.P.; Neto, J.R.; Hide, I.; et al. Eumenitin, a novel antimicrobial peptide from the venom of the solitary eumenine wasp Eumenes rubronotatus. Peptides 2006, 27, 2624-2631. [CrossRef]

66. Vylkova, S.; Sun, J.N.; Edgerton, M. The role of released ATP in killing Candida albicans and other extracellular microbial pathogens by cationic peptides. Purinergic Signal. 2007, 3, 91-97. [CrossRef]

67. Saha, A.K.; Mukherjee, T.; Bhaduri, A. Mechanism of action of amphotericin B on Leishmania donovani promastigotes. Mol. Biochem. Parasitol. 1986, 19, 195-200. [CrossRef]

68. Murray, H.W.; Delph-Etienne, S. Roles of Endogenous Gamma Interferon and Macrophage Microbicidal Mechanisms in Host Response to Chemotherapy in Experimental Visceral Leishmaniasis. Infect. Immun. 2000, 68, 288-293. [CrossRef]

69. Paris, C.; Loiseau, P.M.; Bories, C.; Bréard, J. Miltefosine Induces Apoptosis-Like Death in Leishmania donovani Promastigotes. Antimicrob. Agents Chemother. 2004, 48, 852-859. [CrossRef]

70. Verma, N.K.; Dey, C.S. Possible Mechanism of Miltefosine-Mediated Death of Leishmania donovani. Antimicrob. Agents Chemother. 2004, 48, 3010-3015. [CrossRef]

71. Zuo, X.; Djordjevic, J.T.; Bijosono Oei, J.; Desmarini, D.; Schibeci, S.D.; Jolliffe, K.A.; Sorrell, T.C. Miltefosine Induces ApoptosisLike Cell Death in Yeast via Cox9p in Cytochrome c Oxidase. Mol. Pharmacol. 2011, 80, 476-485. [CrossRef] 
72. Wadhone, P.; Maiti, M.; Agarwal, R.; Kamat, V.; Martin, S.; Saha, B. Miltefosine Promotes IFN- $\gamma$-Dominated Anti-Leishmanial Immune Response. J. Immunol. 2009, 182, 7146-7154. [CrossRef]

73. Murray, H.W.; Montelibano, C.; Peterson, R.; Sypek, J.P. Interleukin-12 Regulates the Response to Chemotherapy in Experimental Visceral Leishmaniasis. J. Infect. Dis. 2000, 182, 1497-1502. [CrossRef]

74. Mookerjee Basu, J.; Mookerjee, A.; Sen, P.; Bhaumik, S.; Sen, P.; Banerjee, S.; Naskar, K.; Choudhuri, S.K.; Saha, B.; Raha, S.; et al. Sodium Antimony Gluconate Induces Generation of Reactive Oxygen Species and Nitric Oxide via Phosphoinositide 3-Kinase and Mitogen-Activated Protein Kinase Activation in Leishmania donovani-Infected Macrophages. Antimicrob. Agents Chemother. 2006, 50, 1788-1797. [CrossRef]

75. Pereira, A.V.; de Barros, G.; Pinto, E.G.; Tempone, A.G.; Orsi, R.d.O.; Dos Santos, L.D.; Calvi, S.; Ferreira, R.S.; Pimenta, D.C.; Barraviera, B. Melittin induces in vitro death of Leishmania (Leishmania) infantum by triggering the cellular innate immune response. J. Venom. Anim. Toxins Incl. Trop. Dis. 2016, 22, 1. [CrossRef]

76. Raghuraman, H.; Chattopadhyay, A. Melittin: A membrane-active peptide with diverse functions. Biosci. Rep. 2007, 27, 189-223. [CrossRef]

77. Adade, C.M.; Chagas, G.S.F.; Souto-Padrón, T. Apis mellifera venom induces different cell death pathways in Trypanosoma cruzi. Parasitology 2012, 139, 1444-1461. [CrossRef]

78. Papo, N.; Shai, Y. Can we predict biological activity of antimicrobial peptides from their interactions with model phospholipid membranes? Peptides 2003, 24, 1693-1703. [CrossRef] [PubMed]

79. Pérez-Cordero, J.J.; Lozano, J.M.; Cortés, J.; Delgado, G. Leishmanicidal activity of synthetic antimicrobial peptides in an infection model with human dendritic cells. Peptides 2011, 32, 683-690. [CrossRef] [PubMed]

80. Adade, C.M.; Oliveira, I.R.S.; Pais, J.A.R.; Souto-Padrón, T. Melittin peptide kills Trypanosoma cruzi parasites by inducing different cell death pathways. Toxicon 2013, 69, 227-239. [CrossRef] [PubMed]

81. Díaz-Achirica, P.; Ubach, J.; Guinea, A.; Andreu, D.; Rivas, L. The plasma membrane of Leishmania donovani promastigotes is the main target for CA(1-8)M(1-18), a synthetic cecropin A-melittin hybrid peptide. Biochem. J. 1998, 330, 453-460. [CrossRef] [PubMed]

82. Mahdavi Abhari, F.; Pirestani, M.; Dalimi, A. Anti-amoebic activity of a cecropin-melittin hybrid peptide (CM11) against trophozoites of Entamoeba histolytica. Wien. Klin. Wochenschr. 2019, 131, 427-434. [CrossRef] [PubMed]

83. Carter, V.; Underhill, A.; Baber, I.; Sylla, L.; Baby, M.; Larget-Thiery, I.; Zettor, A.; Bourgouin, C.; Langel, Ü.; Faye, I.; et al. Killer Bee Molecules: Antimicrobial Peptides as Effector Molecules to Target Sporogonic Stages of Plasmodium. PLoS Pathog. 2013, 9 , e1003790. [CrossRef]

84. Brady, D.; Grapputo, A.; Romoli, O.; Sandrelli, F. Insect cecropins, antimicrobial peptides with potential therapeutic applications. Int. J. Mol. Sci. 2019, 20, 5862. [CrossRef]

85. Akuffo, H.; Hultmark, D.; Engstöm, A.; Frohlich, D.; Kimbrell, D. Drosophila antibacterial protein, cecropin A, differentially affects non-bacterial organisms such as Leishmania in a manner different from other amphipathic peptides. Int. J. Mol. Med. 1998, 1,77-159. [CrossRef]

86. Patiño-Márquez, I.A.; Patiño-González, E.; Hernández-Villa, L.; Ortíz-Reyes, B.; Manrique-Moreno, M. Identification and evaluation of Galleria mellonella peptides with antileishmanial activity. Anal. Biochem. 2018, 546, 35-42. [CrossRef]

87. Hong, S.-M.; Kusakabe, T.; Lee, J.-M.; Tatsuke, T.; Kawaguchi, Y.; Kang, M.-W.; Kang, S.-W.; Kim, K.-A.; Nho, S.-K. Structure and Expression Analysis of the Cecropin-E Gene from the Silkworm. Biotechnol. Biochem. 2008, 72, 1992-1998. [CrossRef]

88. Al-Hyali, N.S.; Khalil, L.Y.; Aljawady, M.A. Sarcotoxin effect on leukocytic finding and phagocytic activity in mice. J. Anim. Vet. Adv. 2009, 8, 2395-2398.

89. Wu, Q.; Patočka, J.; Kuča, K. Insect antimicrobial peptides, a mini review. Toxins 2018, 10, 461. [CrossRef]

90. Ponnuvel, K.M.; Subhasri, N.; Sirigineedi, S.; Murthy, G.N.; Vijayaprakash, N.B. Molecular evolution of the cecropin multigene family in silkworm Bombyx mori. Bioinformation 2010, 5, 97-103. [CrossRef]

91. Yi, H.Y.; Chowdhury, M.; Huang, Y.D.; Yu, X.Q. Insect antimicrobial peptides and their applications. Appl. Microbiol. Biotechnol. 2014, 98, 5807-5822. [CrossRef]

92. Samakovlis, C.; Kimbrell, D.A.; Kylsten, P.; Engstrom, A.; Hultmark, D. The immune response in Drosophila: Pattern of cecropin expression and biological activity. EMBO J. 1990, 9, 2969-2976. [CrossRef]

93. Suttmann, H.; Retz, M.; Paulsen, F.; Harder, J.; Zwergel, U.; Kamradt, J.; Wullich, B.; Unteregger, G.; Stöckle, M.; Lehmann, J. Antimicrobial peptides of the Cecropin-family show potent antitumor activity against bladder cancer cells. BMC Urol. 2008. [CrossRef]

94. Brown, S.E.; Howard, A.; Kasprzak, A.B.; Gordon, K.H.; East, P.D. The discovery and analysis of a diverged family of novel antifungal moricin-like peptides in the wax moth Galleria mellonella. Insect Biochem. Mol. Biol. 2008, 8, 5. [CrossRef]

95. Gwadz, R.W.; Kaslow, D.; Lee, J.Y.; Maloy, W.L.; Zasloff, M.; Miller, L.H. Effects of magainins and cecropins on the sporogonic development of malaria parasites in mosquitoes. Infect. Immun. 1989, 57, 2628-2633. [CrossRef] [PubMed]

96. Kim, W.; Koo, H.; Richman, A.M.; Seeley, D.; Vizioli, J.; Klocko, A.D.; O’Brochta, D.A. Ectopic expression of a cecropin transgene in the human malaria vector mosquito Anopheles gambiae (Diptera: Culicidae): Effects on susceptibility to Plasmodium. J. Med. Entomol. 2004, 41, 447-455. [CrossRef]

97. Boulanger, N.; Brun, R.; Ehret-Sabatier, L.; Kunz, C.; Bulet, P. Immunopeptides in the defense reactions of Glossina morsitans to bacterial and Trypanosoma brucei brucei infections. Insect Biochem. Mol. Biol. 2002, 32, 369-375. [CrossRef] 
98. Jaynes, J.M.; Burton, C.A.; Barr, S.B.; Jeffers, G.W.; Julian, G.R.; White, K.L.; Enright, F.M.; Klei, T.R.; Laine, R.A. In vitro cytocidal effect of novel lytic peptides on Plasmodium falciparum and Trypanosoma cruzi. FASEB J. Off. Publ. Fed. Am. Soc. Exp. Biol. 1988, 2, 2878-2883. [CrossRef]

99. Kościuczuk, E.M.; Lisowski, P.; Jarczak, J.; Strzałkowska, N.; Jóźwik, A.; Horbańczuk, J.; Krzyżewski, J.; Zwierzchowski, L.; Bagnicka, E. Cathelicidins: Family of antimicrobial peptides. A review. Mol. Biol. Rep. 2012, 39, 10957-10970. [CrossRef]

100. Galloo, R.L.; Kim, K.J.; Bernfield, M.; Kozak, C.A.; Zanetti, M.; Merluzzi, L.; Gennaro, R. Identification of CRAMP, a cathelinrelated antimicrobial peptide expressed in the embryonic and adult mouse. J. Biol. Chem. 1997, 272, 13088-13093. [CrossRef]

101. Chen, J.; Shin, V.Y.; Ho, J.C.W.; Siu, M.T.; Cheuk, I.W.Y.; Kwong, A. Functional implications of cathelicidin antimicrobial protein in breast cancer and tumor-associated macrophage microenvironment. Biomolecules 2020, 10, 688. [CrossRef]

102. Crauwels, P.; Bank, E.; Walber, B.; Wenzel, U.A.; Agerberth, B.; Chanyalew, M.; Abebe, M.; König, R.; Ritter, U.; Reiling, N.; et al. Cathelicidin Contributes to the Restriction of Leishmania in Human Host Macrophages. Front. Immunol. 2019, 10, 2697. [CrossRef]

103. Das, S.; Sardar, A.H.; Abhishek, K.; Kumar, A.; Rabidas, V.N.; Das, P. Cathelicidin augments VDR-dependent anti-leishmanial immune response in Indian Post-Kala-Azar Dermal Leishmaniasis. Int. Immunopharmacol. 2017, 50, 130-138. [CrossRef]

104. Marr, A.K.; Cen, S.; Hancock, R.E.W.; McMaster, W.R. Identification of synthetic and natural host defense peptides with leishmanicidal activity. Antimicrob. Agents Chemother. 2016, 60, 2484-2491. [CrossRef] [PubMed]

105. Lynn, M.A.; Kindrachuk, J.; Marr, A.K.; Jenssen, H.; Panté, N.; Elliott, M.R.; Napper, S.; Hancock, R.E.; McMaster, W.R. Effect of BMAP-28 antimicrobial peptides on Leishmania major promastigote and amastigote growth: Role of leishmanolysin in parasite survival. PLoS Negl. Trop. Dis. 2011, 5, e1141. [CrossRef] [PubMed]

106. Cauchard, S.; Van Reet, N.; Büscher, P.; Goux, D.; Grötzinger, J.; Leippe, M.; Cattoir, V.; Laugier, C.; Cauchard, J. Killing of trypanozoon parasites by the equine cathelicidin eCATH1. Antimicrob. Agents Chemother. 2016, 60, 2610-2619. [CrossRef] [PubMed]

107. Fang, Y.; He, X.; Zhang, P.; Shen, C.; Mwangi, J.; Xu, C.; Mo, G.; Lai, R.; Zhang, Z. In vitro and in vivo antimalarial activity of LZ1, a peptide derived from snake cathelicidin. Toxins 2019, 11, 379. [CrossRef]

108. Meade, K.G.; O'Farrelly, C. B-Defensins: Farming the microbiome for homeostasis and health. Front. Immunol. 2019, 10, 1-20. [CrossRef]

109. Dong, H.; Lv, Y.; Zhao, D.; Barrow, P.; Zhou, X. Defensins: The Case for Their Use against Mycobacterial Infections. J. Immunol. Res. 2016, 2016, 7515687. [CrossRef]

110. Kerenga, B.K.; McKenna, J.A.; Harvey, P.J.; Quimbar, P.; Garcia-Ceron, D.; Lay, F.T.; Phan, T.K.; Veneer, P.K.; Vasa, S.; Parisi, K.; et al. Salt-Tolerant Antifungal and Antibacterial Activities of the Corn Defensin ZmD32. Front. Microbiol. 2019, 10, 795. [CrossRef]

111. Daneshvar, H.; Tavakoli Kareshk, A.; Sharifi, I.; Keyhani, A.; Tavakoli Oliaee, R.; Asadi, A. Host-parasite responses outcome regulate the expression of antimicrobial peptide genes in the skin of BALB/c and c57bl/6 murine strains following leishmania major MRHO/IR/75/ER infection. Iran. J. Parasitol. 2018, 13, 515-523.

112. Souza, G.S.; de Carvalho, L.P.; de Melo, E.J.T.; da Silva, F.C.V.; Machado, O.L.T.; Gomes, V.M.; de Oliveira Carvalho, A. A synthetic peptide derived of the $\beta 2-\beta 3$ loop of the plant defensin from Vigna unguiculata seeds induces Leishmania amazonensis apoptosis-like cell death. Amino Acids 2019, 51, 1633-1648. [CrossRef]

113. Pero, R.; Coretti, L.; Nigro, E.; Lembo, F.; Laneri, S.; Lombardo, B.; Daniele, A.; Scudiero, O. $\beta$-defensins in the fight against Helicobacter pylori. Molecules 2017, 22, 424. [CrossRef]

114. Polesello, V.; Segat, L.; Crovella, S.; Zupin, L. Candida Infections and Human Defensins. Protein Pept. Lett. 2017, 24, 747-756. [CrossRef]

115. Yoo, Y.J.; Kwon, I.; Oh, S.R.; Perinpanayagam, H.; Lim, S.M.; Ahn, K.B.; Lee, Y.; Han, S.H.; Chang, S.W.; Baek, S.H.; et al. Antifungal Effects of Synthetic Human Beta-defensin-3-C15 Peptide on Candida albicans-infected Root Dentin. J. Endod. 2017, 43, 1857-1861. [CrossRef]

116. Wilson, S.S.; Wiens, M.E.; Smith, J.G. Antiviral mechanisms of human defensins. J. Mol. Biol. 2013, 425, 4965-4980. [CrossRef]

117. Holly, M.K.; Diaz, K.; Smith, J.G. Defensins in Viral Infection and Pathogenesis. Annu. Rev. Virol. 2017, 4, 369-391. [CrossRef]

118. Sarkar, P.; Jana, K.; Sikdar, S.R. Overexpression of biologically safe Rorippa indica defensin enhances aphid tolerance in Brassica juncea. Planta 2017, 246, 1029-1044. [CrossRef]

119. Cabezas-cruz, A.; Tonk, M.; Bouchut, A.; Pierrot, C.; Pierce, R.J.; Kotsyfakis, M.; Rahnamaeian, M.; Vilcinskas, A.; Khalife, J.; Valdés, J.J. Antiplasmodial Activity Is an Ancient and Conserved Feature of Tick Defensins. Front. Microbiol. 2016, 7, 1682. [CrossRef]

120. Couto, J.; Tonk, M.; Ferrolho, J.; Antunes, S.; Vilcinskas, A.; de la Fuente, J.; Domingos, A.; Cabezas-Cruz, A. Antiplasmodial activity of tick defensins in a mouse model of malaria. Ticks Tick. Borne. Dis. 2018, 9, 844-849. [CrossRef]

121. Morampudi, V.; Braun, M.Y.; Souza, S.D. Modulation of Early $\beta$-Defensin-2 Production as a Mechanism Developed by Type I Toxoplasma gondii To Evade Human Intestinal Immunity. Infect. Immun. 2011, 79, 2043-2050. [CrossRef]

122. Carryn, S.; Schaefer, D.A.; Imboden, M.; Homan, E.J.; Bremel, R.D.; Riggs, M.W. Phospholipases and Cationic Peptides Inhibit Cryptosporidium parvum Sporozoite Infectivity by Parasiticidal and Non-Parasiticidal Mechanisms. J. Parasitol. 2012, 98, 199-204. [CrossRef]

123. Pino-Angeles, A.; Leveritt, J.M.; Lazaridis, T. Pore Structure and Synergy in Antimicrobial Peptides of the Magainin Family. PLoS Comput. Biol. 2016, 12, 1004570. [CrossRef]

124. Pincus, M. Physiological structure and function of proteins. Cell Physiol. Source Book 2012, 19-42. [CrossRef] 
125. Bagheri, M. Aggregation vs. Fusion of Negatively Charged Lipid Bilayers Induced by Bactenecin and Magainin Derivatives. Biophys. J. 2018, 114, 453a. [CrossRef]

126. Hasan, M.; Karal, M.A.S.; Levadnyy, V.; Yamazaki, M. Mechanism of Initial Stage of Pore Formation Induced by Antimicrobial Peptide Magainin 2. Langmuir 2018, 34, 3349-3362. [CrossRef]

127. Bacalum, M.; Radu, M. Cationic Antimicrobial Peptides Cytotoxicity on Mammalian Cells: An Analysis Using Therapeutic Index Integrative Concept. Int. J. Pept. Res. Ther. 2015, 21, 47-55. [CrossRef]

128. Patocka, J.; Nepovimova, E.; Klimova, B.; Wu, Q.; Kuca, K. Antimicrobial Peptides: Amphibian Host Defense Peptides. Curr. Med. Chem. 2018, 26, 5924-5946. [CrossRef]

129. Nyström, L.; Malmsten, M. Membrane interactions and cell selectivity of amphiphilic anticancer peptides. Curr. Opin. Colloid Interface Sci. 2018, 38, 1-17. [CrossRef]

130. Guerrero, E.; Saugar, J.M.; Matsuzaki, K.; Rivas, L. Role of positional hydrophobicity in the leishmanicidal activity of magainin 2. Antimicrob. Agents Chemother. 2004, 48, 2980-2986. [CrossRef]

131. Kulkarni, M.M.; Karafova, A.; Kamysz, W.; McGwire, B.S. Design of protease-resistant pexiganan enhances antileishmanial activity. Parasitol. Res. 2014, 113, 1971-1976. [CrossRef] [PubMed]

132. Giacometti, A.; Cirioni, O.; Simona, M.; Prete, D.E.L.; Barchiesi, F. Short-Term Exposure to Membrane-Active Antibiotics Inhibits Cryptosporidium parvum Infection in Cell Culture. Antimicrob. Agents Chemother. 2000, 44, 3473-3475. [CrossRef] [PubMed]

133. Ladram, A.; Nicolas, P. Antimicrobial peptides from frog skin: Biodiversity and therapeutic promises. Front. Biosci.-Landmark 2016, 21, 1341-1371. [CrossRef] [PubMed]

134. Crépin, A.; Jégou, J.-F.; André, S.; Ecale, F.; Croitoru, A.; Cantereau, A.; Berjeaud, J.-M.; Ladram, A.; Verdon, J. In vitro and intracellular activities of frog skin temporins against Legionella pneumophila and its eukaryotic hosts. Sci. Rep. 2020, 1, 3978. [CrossRef]

135. Maisetta, G.; Grassi, L.; Di Luca, M.; Bombardelli, S.; Medici, C.; Brancatisano, F.L.; Esin, S.; Batoni, G. Anti-biofilm properties of the antimicrobial peptide temporin $1 \mathrm{~Tb}$ and its ability, in combination with EDTA, to eradicate Staphylococcus epidermidis biofilms on silicone catheters. Biofouling 2016, 32, 787-800. [CrossRef]

136. Marimuthu, S.K.; Nagarajan, K.; Perumal, S.K.; Palanisamy, S.; Subbiah, L. Insilico Alpha-Helical Structural Recognition of Temporin Antimicrobial Peptides and Its Interactions with Middle East Respiratory Syndrome-Coronavirus. Int. J. Pept. Res. Ther. 2020, 26, 1473-1483. [CrossRef]

137. Mishra, B.; Wang, X.; Lushnikova, T.; Zhang, Y.; Golla, R.M.; Narayana, J.L.; Wang, C.; McGuire, T.R.; Wang, G. Antibacterial, antifungal, anticancer activities and structural bioinformatics analysis of six naturally occurring temporins. Peptides 2018, 106, 9-20. [CrossRef]

138. Holden, W.M.; Reinert, L.K.; Hanlon, S.M.; Parris, M.J.; Rollins-Smith, L.A. Development of antimicrobial peptide defenses of southern leopard frogs, Rana sphenocephala, against the pathogenic chytrid fungus, Batrachochytrium dendrobatidis. Dev. Comp. Immunol. 2015, 48, 65-75. [CrossRef]

139. Abbassi, F.; Humblot, V.; Lequin, O.; Raja, Z.; Andre, S.; Bouceba, T.; Correia, I.; Casale, S.; Foulon, T.; Sereno, D.; et al. Insight into the mechanism of action of temporin-SHa, a new broad-spectrum antiparasitic and antibacterial agent. PLoS ONE 2017, 12, e0174024. [CrossRef]

140. Swithenbank, L.; Cox, P.; Harris, L.G.; Dudley, E.; Sinclair, K.; Lewis, P.; Cappiello, F.; Morgan, C. Temporin A and Bombinin H2 Antimicrobial Peptides Exhibit Selective Cytotoxicity to Lung Cancer Cells. Scientifica 2020, 2020, 3526286. [CrossRef]

141. Mangoni, M.L.; Saugar, J.M.; Dellisanti, M.; Barra, D.; Simmaco, M.; Rivas, L. Temporins, small antimicrobial peptides with leishmanicidal activity. J. Biol. Chem. 2005, 280, 984-990. [CrossRef]

142. André, S.; Raja, Z.; Humblot, V.; Piesse, C.; Foulon, T.; Sereno, D.; Oury, B.; Ladram, A. Functional characterization of temporinshe, a new broad-spectrum antibacterial and leishmanicidal temporin-sh paralog from the Sahara frog (Pelophylax saharicus). Int. J. Mol. Sci. 2020, 21, 6713. [CrossRef]

143. Souza, A.L.A.; Faria, R.X.; Calabrese, K.S.; Hardoim, D.J. Temporizin and Temporizin-1 Peptides as Novel Candidates for Eliminating Trypanosoma cruzi. PLoS ONE 2016, 11, e0157673. [CrossRef]

144. Feder, R.; Dagan, A.; Mor, A. Structure-activity relationship study of antimicrobial dermaseptin S4 showing the consequences of peptide oligomerization on selective cytotoxicity. J. Biol. Chem. 2000, 275, 4230-4238. [CrossRef]

145. Lequin, O.; Ladram, A.; Chabbert, L.; Bruston, F.; Convert, O.; Vanhoye, D.; Chassaing, G.; Nicolas, P.; Amiche, M. Dermaseptin S9, an R-Helical Antimicrobial Peptide with a Hydrophobic Core and Cationic Termini. Biochemistry 2006, 45, 468-480. [CrossRef]

146. Chaves, R.X.; Quelemes, P.V.; Leite, L.M.; Aquino, D.S.A.; Amorim, L.V.; Rodrigues, K.A.F.; Campelo, Y.D.M.; Veras, L.M.; Bemquerer, M.P.; Ramos-Jesus, J.; et al. Antileishmanial and Immunomodulatory Effects of Dermaseptin-01, A Promising Peptide Against Leishmania amazonensis. Curr. Bioact. Compd. 2016, 13, 1. [CrossRef]

147. Salay, L.C.; Nobre, T.M.; Colhone, M.C.; Zaniquelli, M.E.D.; Ciancaglini, P.; Stabeli, R.G.; Leite, J.R.S.A.; Zucolotto, V. Dermaseptin 01 as antimicrobial peptide with rich biotechnological potential: Study of peptide interaction with membranes containing Leishmania amazonensis lipid-rich extract and membrane models. J. Pept. Sci. 2011, 17, 700-707. [CrossRef]

148. Yang, Z.; Zheng, J.; Chan, C.F.; Wong, I.L.K.; Heater, B.S.; Chow, L.M.C.; Lee, M.M.M.; Chan, M.K. Targeted delivery of antimicrobial peptide by Cry protein crystal to treat intramacrophage infection. Biomaterials 2019, 217, 119286. [CrossRef]

149. Nascimento, C.; Miura, L.M.C.V.; Nakano, E.; Kawano, T.; Sa, U.D.; Ministro, C.; Velloso, R. Evaluation of the in vitro Activity of Dermaseptin 01, a Cationic Antimicrobial Peptide, against Schistosoma mansoni. Chem. Biodivers. 2011, 8, 548-558. 
150. Cruzi, A.; Brand, G.D.; Leite, J.R.S.A.; Silva, L.P.; Albuquerque, S.; Prates, V.; Azevedo, R.B.; Silva, J.S.; Sá, V.C.L.; Brandão, R.A.; et al. Protein Structure and Folding: Dermaseptins from Phyllomedusa oreades and Phyllomedusa distincta: ACTIVITY without Cytotoxicity Dermaseptins from Phyllomedusa oreades and Phyllomedusa distincta. J. Biol.Chem. 2002, 277, 49332-49340. [CrossRef]

151. Leite, S.A.; Silva, L.P.; Izabel, M.; Rodrigues, S.; Prates, M.V.; Brand, G.D.; Lacava, B.M.; Azevedo, R.B.; Bocca, L.; Albuquerque, S.; et al. Phylloseptins: A novel class of anti-bacterial and anti-protozoan peptides from the Phyllomedusa genus. Peptides 2005, 26, 565-573. [CrossRef]

152. Sabiá, E.F.; Menezes, L.F.S.; De Araújo, I.F.S.; Schwartz, E.F. Natural occurrence in venomous arthropods of antimicrobial peptides active against protozoan parasites. Toxins 2019, 11, 563. [CrossRef]

153. Rangel, M.; Dos Santas Cabrera, M.P.; Kazuma, K.; Ando, K.; Wang, X.; Kato, M.; Nihei, K.; Hirata, I.Y.; Cross, T.J.; Garcia, A.N.; et al. Chemical and biological characterization of four new linear cationic $\alpha$-helical peptides from the venoms of two solitary eumenine wasps. Toxicon 2011, 57, 1081-1092. [CrossRef]

154. Dale, B.A.; Fredericks, L.P. Antimicrobial peptides in the oral environment: Expression and function in health and disease. Curr. Issues Mol. Biol. 2005, 7, 119-133. [CrossRef] [PubMed]

155. Khurshid, Z.; Najeeb, S.; Mali, M.; Moin, S.F.; Raza, S.Q.; Zohaib, S.; Sefat, F.; Zafar, M.S. Histatin peptides: Pharmacological functions and their applications in dentistry. Saudi Pharm. J. 2017, 25, 25-31. [CrossRef] [PubMed]

156. Hajishengallis, G.; Russell, M.W. Innate Humoral Defense Factors. In Mucosal Immunology; Elsevier: Amsterdam, The Netherlands, 2015; pp. 251-270.

157. Luque-Ortega, J.R.; Hof, W.; Veerman, E.C.I.; Saugar, J.M.; Rivas, L. Human antimicrobial peptide histatin 5 is a cell-penetrating peptide targeting mitochondrial ATP synthesis in Leishmania. FASEB J. 2008, 22, 1817-1828. [CrossRef] [PubMed]

158. Shahrour, H.; Ferrer-Espada, R.; Dandache, I.; Bárcena-Varela, S.; Sánchez-Gómez, S.; Chokr, A.; Martinez-de-Tejada, G. AMPs as Anti-biofilm Agents for Human Therapy and Prophylaxis. Adv. Exp. Med. Biol. 2019, 1117, 257-279. [CrossRef] [PubMed] 